\title{
Alternative splicing of fosB transcripts results in differentially expressed mRNAs encoding functionally antagonistic proteins
}

\author{
Dominik Mumberg, ${ }^{1}$ Frances C. Lucibello, ${ }^{1}$ Marcus Schuermann,, ${ }^{1}$ and Rolf Müller ${ }^{2}$ \\ Institut für Molekularbiologie und Tumorforschung (IMT), Philipps-Universität Marburg, Marburg, Germany
}

\begin{abstract}
We show that serum-stimulated fibroblasts transiently express two different forms of fos $B$ mRNA, which are generated by alternative splicing of the transcript from a single gene. In addition to the known long form (fosB-L), encoding a protein of $\mathbf{3 3 8}$ amino acids (FosB-L), a second shorter form (fosB-S) with a deletion of 140 bp was detected. This deletion creates a stop codon $3^{\prime}$ to the leucine repeat, giving rise to a protein of 237 amino acids (FosB-S) lacking the carboxyl terminus of FosB-L. Only the long FosB form efficiently induces transformation in mouse and rat fibroblast cell lines and trans-represses the c-fos promoter. Both of these functions are suppressed by coexpressed FosB-S. Upon serum stimulation, maximum expression of the oncogenic fos $B$ - $L$ form precedes the expression of the antagonistic fos $B-S$ form, indicating a new mechanism regulating the action of members of the Fos family. However, FosB-L and FosB-S do not differ in all trans-regulatory properties: Trans-activation of a 5X TRE-CAT reporter construct in HeLa and NIH-3T3 cells was found with both FosB forms. These observations suggest a correlation between fosB-induced transformation and trans-repression, thus pointing to different mechanisms involved in transformation by fosB and c-fos/v-fos.
\end{abstract}

[Key Words: fosB; proto-oncogene; anti-oncogene; splicing; trans-regulation; transformation]

Received February 21, 1991; revised version accepted April 18, 1991.

A large number of genes have been identified that are part of the immediate early response to growth factor stimulation (Cochran et al. 1983; Kelly et al. 1983; Greenberg and Ziff 1984; Kruijer et al. 1984; Müller et al. 1984; Almendral et al. 1988; Ryseck et al. 1988). A vast number of these genes encode nuclear DNA-binding proteins, some of which have been identified as transcription factors (for a review, see Herrlich and Ponta 1989). It has been shown in a number of cases that such genes are subject to cross-regulation, autorepression, or autostimulation and that in many cases their products interact to form active transcription complexes or to antagonize each other. All of these observations indicate a complex network of regulatory transcriptional and post-transcriptional mechanisms following growth factor stimulation.

Among the immediate early genes encoding nuclear trans-regulatory proteins are the members of the Fos and Jun families (Cohen and Curran 1988a, 1989a; Ryder et al. 1988, 1989; Hirai et al. 1989; Zerial et al. 1989; Matsui et al. 1990, Nishina et al. 1990) that can interact in any combination to form heterodimeric Fos/Jun complexes and constitute (part of) the transcription factor

\footnotetext{
${ }^{1}$ These authors contributed equally to this work.

${ }^{2}$ Corresponding author.
}

AP-1 (Angel et al. 1987; Lee et al. 1987; Chiu et al. 1988; Halazonetis et al. 1988; Nakabeppu et al. 1988; Rauscher et al. 1988a,b; Sassone-Corsi et al. 1988a; for review, see Curran and Franza 1988). However, not all Fos/Jun complexes behave in a similar way with regard to the regulation of AP-1-dependent transcription. While a c-Fos/ c-Jun complex is a transcriptional activator (Chiu et al. 1988; Lucibello et al. 1988; Sassone-Corsi et al. 1988a; Schönthal et al. 1988), JunB acts as a repressor (Schütte et al. 1989). In addition to a role in the control of AP-1dependent gene expression, the c-Fos protein has transrepressing functions that are independent of DNA binding, including the repression of the c-fos promoter (Sassone-Corsi et al. 1988b; König et al. 1989; Lucibello et al. 1989) and of glucocorticoid receptor-dependent transcription (Jonat et al. 1990; Lucibello et al. 1990).

The $f_{O S} B$ gene was identified by screening a cDNA library of serum-induced genes with an oligonucleotide representing the conserved DNA-binding site in Fos (Zerial et al. 1989). Sequence analysis of the isolated cDNA revealed an open reading frame of 338 amino acids, encompassing the known structural features of Fos proteins, that is, a basic domain involved in DNA binding and a leucine zipper as the dimerization interface (Kouzarides and Ziff 1988; Gentz et al. 1989; Neuberg et 
al. 1989; Schuermann et al. 1989; Turner and Tjian 1989|. The formation of FosB/Jun complexes and their interaction with the AP-1 site [also referred to as TPA responsive element (TRE)] was shown in in vitro complex reconstitution and gel-retardation assays (Zerial et al. 1989|. These analyses also suggested that FosB and c-Fos proteins do not differ in the properties investigated. The only known functional difference between the two proteins is the recently reported repression of the glucocorticoid receptor by c-Fos/v-Fos but not by FosB (Lucibello et al. 1990).

The deregulation of c-fos expression suffices to induce morphological transformation in rodent fibroblast cell lines (Miller et al. 1984; Meijlink et al. 1985). Structural alterations in the protein, as they occur in v-Fos, enhance the transforming properties and can activate the immortalizing potential (Jenuwein and Müller 1987). The mechanism by which transformation is brought about remains, however, largely obscure. Although an intact leucine zipper, a functional DNA-binding site and the ability to trans-activate AP-1-dependent transcription are prerequisites for transformation, they are not sufficient (Schuermann et al. 1989; Lucibello et al. 1991; Neuberg et al. 1991). Even less is known about the mechanisms involved in FosB-induced transformation, which is partly due to the fact that FosB is poorly characterized in molecular terms.

Here, we report that the fos $B$ transcript is subject to alternative splicing. Two mRNA forms are consecutively expressed following serum stimulation and show antagonistic properties with respect to transformation and trans-repression. Of particular interest is the observation that only the long form of FosB is able to transform fibroblasts efficiently and to trans-repress, and that both of these functions are counteracted by the short form. Our results point to a new regulatory mechanism governing the trans-regulation of gene expression by Fos family members and suggest that different trans-regulatory functions are involved in the transformation by different members of the Fos family.

\section{Results}

Two forms of fosB $m R N A$ are induced by serum stimulation

In the course of experiments dealing with the delineation of exon-intron boundaries in the mouse fos $B$ gene, we obtained results that were not compatible with the published sequence of a fos $B$ cDNA (Zerial et al. 1989). A closer inspection of the nucleotide sequence revealed the presence of potential splice donor (SD; AG/GTGAGA) and splice acceptor (SA; CAG) sites in fos $B$ transcripts (see Fig. la), which might result in the expression of an alternative mRNA. To test this hypothesis we synthesized a set of primers $\left(5^{\prime} p\right.$ and $3^{\prime} p$ in Fig. 1a) to amplify cDNAs (Saiki et al. 1988) synthesized from various cell types in different conditions of proliferation or differentiation. The known longer fos $B$ mRNA ( $O S B-\mathrm{L})$ should generate an amplified 322-bp fragment, whereas a

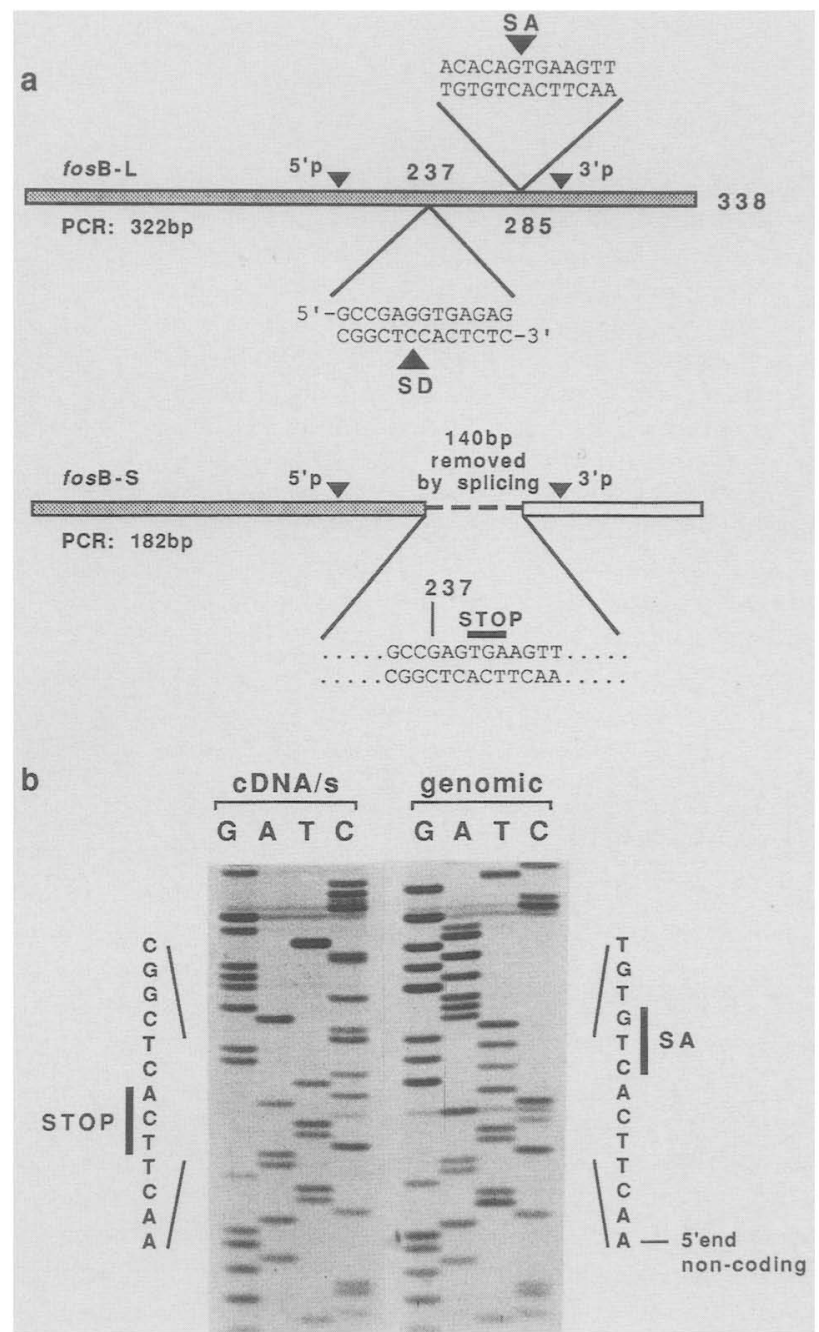

Figure 1. (a) Schematic representation of $f o s B-\mathrm{L}($ top $)$ and fos $B$ $S$ (bottom) cDNAs. (SA and SD) Splice acceptor and splice donor consensus sequences, respectively; numbers refer to amino acid positions. Removal of an additional $140 \mathrm{bp}$ by alternative splicing generates a carboxy-terminally truncated protein by creation of a stop codon $3^{\prime}$ to amino acid position $237 . \mid 5^{\prime} \mathrm{p}$ and $3^{\prime} \mathrm{p}$ ) Positions of the primers used for PCR-mediated cDNA amplification. fos $B$-L generates a 322-bp fragment; fos $B$-S generates a 182 -bp fragment. Stippled boxes indicate coding regions; the open box in FosB-S represents the untranslated sequence $3^{\prime}$ to the stop codon created by alternative splicing. $(b)$ Nucleotide sequence analysis of the region where the alternative splicing occurs (splice junction) in the cloned PCR product representing the fos $B$-S cDNA (cDNA/s; left) and the genomic fos $B$ DNA (right). The sequences represent the lower (noncoding) strands, with the $5^{\prime}$ end at the bottom. The positions of the stop codon in $f O S B-S$ and of the SA in the upper strands are also shown.

shorter form (fos $B$-S) generated by alternative splicing should give rise to a fragment of $182 \mathrm{bp}$ (see Fig. la). The results of this analysis are shown in Figure 2. No significant $f \circ s B$ expression was observed in undifferentiated or differentiated F9 cells (F9EC, F9END), normally growing HeLa, NIH-3T3, or $208 \mathrm{~F}$ cells, and serum-deprived 
Figure 2. Analysis of $f \circ s B-\mathrm{L}$ and $f \circ S B-S$ expression by quantitative PCR-mediated CDNA amplification in different cell lines. (F9 EC) Undifferentiated F9 embryonal carcinoma cells; (F9 END) F9 cells differentiating to parietal endoderm after 4 days of exposure to retinoic acid plus dibutyryl-cAMP; (-FCS) $24 \mathrm{hr}$ after withdrawal of senum; (growing) normally proliferating cells in 10\% FCS; (stimulated) serumdeprived cells stimulated with $10 \%$ FCS for $1 \mathrm{hr}$; (no RNA) negative control. The two PCR products of 322 and $182 \mathrm{bp}$, representing the long and short forms of fos $B$ mRNA (fos $B$-L and $f o s B-S$, respectively), are indicated by arrows. The origin of the weak band above fos $B-\mathrm{L}$ is unknown.

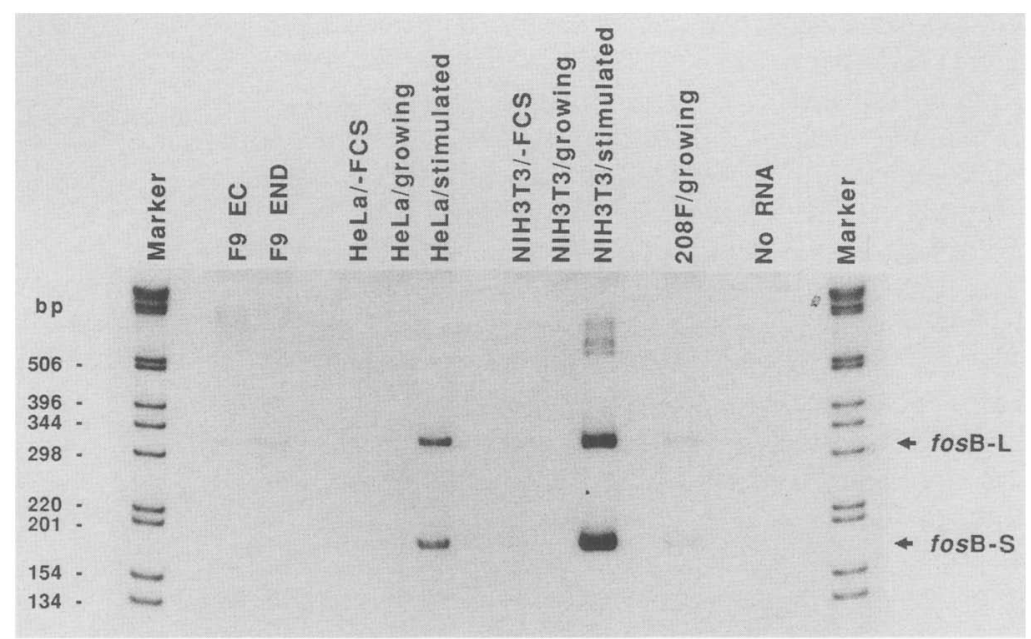

(-FCS) HeLa or NIH-3T3 cells. In contrast, strong expression was observed in serum-stimulated HeLa and NIH-3T3 cells. In both cases, the two fragments predicted for $f \circ s B$-L and fos $B$-S mRNAs were found. Taken together with the fact that the expression patterns of both mRNAs followed the known expression of $f \circ B$ mRNA (Zerial et al. 1989), our observations suggest that serum stimulation leads to the induction of two fos $B$ mRNAs generated by alternative splicing.

To verify this conclusion we isolated the smaller amplified fragment by agarose gel electrophoresis and cloned it in PTZ18R. The DNA sequence of the insert was determined and compared to the corresponding region of a recombinant phage ( $\lambda f \circ s B)$, which contained a $13-\mathrm{kb}$ insert encompassing the mouse (BALB/c) fos $B$ gene (D. Mumberg, M. Schuermann, and R. Müller, in prep.). The sequences of the relevant regions around the splice junction are shown in Figure $1 \mathrm{~b}$. It is clearly visible that the sequence of $f \circ S B$-S is identical to the genomic sequence until the position of the SA site is reached, indicating that the alternative splicing event took place as expected. The remaining sequence for fos $B$-S, as pre- dicted in Figure 1a, was also confirmed by sequence analysis, including the presence of the stop codon TGA.

\section{The two fosB $m R N A$ forms are derived from a single gene}

To verify that the two mRNA forms are generated by alternative splicing of a single primary transcript rather than by transcription of two $\operatorname{fos} B$ genes, we performed Southern blot analyses of mouse genomic DNA and compared the observed pattern with the restriction map established for the $\lambda$ fosB phage described above (Fig. 3). Mouse liver DNA was digested with BamHI, Xhol, or SacI, and the blot was hybridized to a cDNA probe covering the entire coding region, as indicated in Figure $3 \mathrm{a}$. The observed number of hybridizing fragments (two for $\mathrm{SaCI}$ and $\mathrm{BamHI}$; one for XhoI), as well as their sizes (10.0 and $1.8 \mathrm{~kb}$ for SacI; 4.8 and $3.0 \mathrm{~kb}$ for BamHI; $\sim 14 \mathrm{~kb}$ for $\mathrm{XhoI}$, is in perfect agreement with that of the isolated phage, demonstrating that all fragments were derived from a single gene. This result therefore supports the

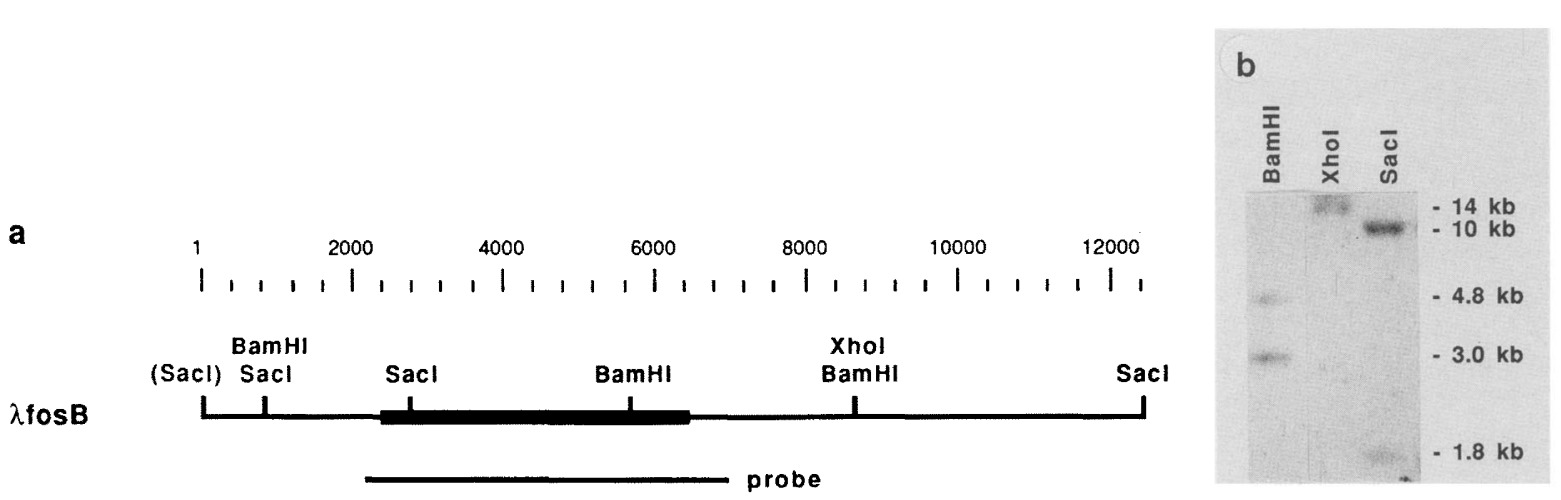

Figure 3. (a) Restriction map of a recombinant phage isolated from a BALB/c mouse liver genomic library. The SacI site shown in parentheses is derived from the phage vector. Numbers at the top indicate nucleotide positions. (b) Southern blot analysis of mouse genomic DNA digested with BamHI, XhoI, or SacI and hybridized to a cDNA probe covering the region indicated in $a$. 
conclusion that $f \circ B-\mathrm{L}$ and $f \circ S B-S$ are generated by alternative splicing.

We also sought to confirm the presence of two alternatively spliced RNAs by nuclease S1 mapping. A probe covering the splice junction in $f O S B$-S was generated by isolating a genomic BamHI-SphI fosB fragment. This probe should give rise to a fragment of $884 \mathrm{bp}$ protected by fos $B$-L mRNA and a fragment of 590 bp protected by fos $B$-S mRNA (see Fig. 4a). Fragments of these sites were indeed detected when RNA from stimulated NIH-3T3 cells was analyzed in a nuclease $\mathrm{S} 1$ protection assay (Fig. $4 \mathrm{~b}$; 3T3-S), using two different enzyme concentrations (200 and 400 units). In contrast, no protected fragments were observed with RNA from unstimulated cells (3T3Q|, underscoring the specificity of the results.

\section{Differential expression of fosB- $L$ and fosB-S after serum stimulation}

We investigated the temporal expression of the two fos $B$ mRNA forms after serum stimulation. Serum-deprived NIH-3T3 cells were stimulated with $10 \%$ FCS, and RNA was isolated for $0,15,30,60,90$, and 120 min poststimulation, transcribed into cDNAs, and amplified by polymerase chain reaction (PCR) (Saiki et al. 1988). The PCR conditions were established such that amplification of the cDNAs was linearly dependent on the concentration of the corresponding mRNAs. This was achieved by performing the reactions in the presence of $\left[\alpha^{-32} \mathrm{P}\right] \mathrm{dCTP}$, so that owing to the greater sensitivity of autoradiography as opposed to ethidium bromide staining, a relatively low number of PCR cycles was sufficient to detect the amplified products. In this way, the cDNA concentration remained the rate-limiting factor throughout the amplification procedure (D. Mumberg et al., unpubl.).
For control purposes, the RNA was also analyzed by Northern blotting using a $\operatorname{fos} B$ cDNA as the probe.

Figure 5a shows that the expression of fos $B$ mRNA in our experiment followed the known kinetics, and hybridization to a GAPDH probe indicates that equal amounts of intact RNA were used for each time point. The PCR analysis in Figure $5 b$ revealed a clearly differential expression of both $\operatorname{fos} B$ mRNA forms. Although fos $B$-L showed maximum expression at 15-30 min, fos $B$ $S$ appeared later, peaking $\sim 60 \mathrm{~min}$ poststimulation. In contrast, $\beta$-actin, which was included as a control, showed no significant variation in the level of expression. These experiments were performed three times with independently isolated RNA samples, and fos $B-\mathrm{L}$ mRNA clearly preceded the shorter form each time (data not shown).

Serum stimulation was also performed in the presence of the protein synthesis inhibitor cycloheximide (CHX) to analyze whether expression of FosB-L protein is necessary for the synthesis of fosB-S mRNA (Fig. 5b). This does not seem to be the case, because the short RNA form appeared also in the presence of $\mathrm{CHX}$ and even seemed to be expressed at higher levels than fos $B$-L. As expected, mRNA degradation was largely prevented by $\mathrm{CHX}$, leading to a stable induction of both $\operatorname{fos} B-\mathrm{L}$ and fos $B$-S during the period analyzed in the present experiment.

\section{Construction of fosB genes encoding specific protein forms}

The differential expression of $f \circ s B-\mathrm{L}$ and $f \circ s B-S$ raised the intriguing possibility that the short form might encode a protein that counteracts the preceding action of the longer counterpart. According to this hypothesis,
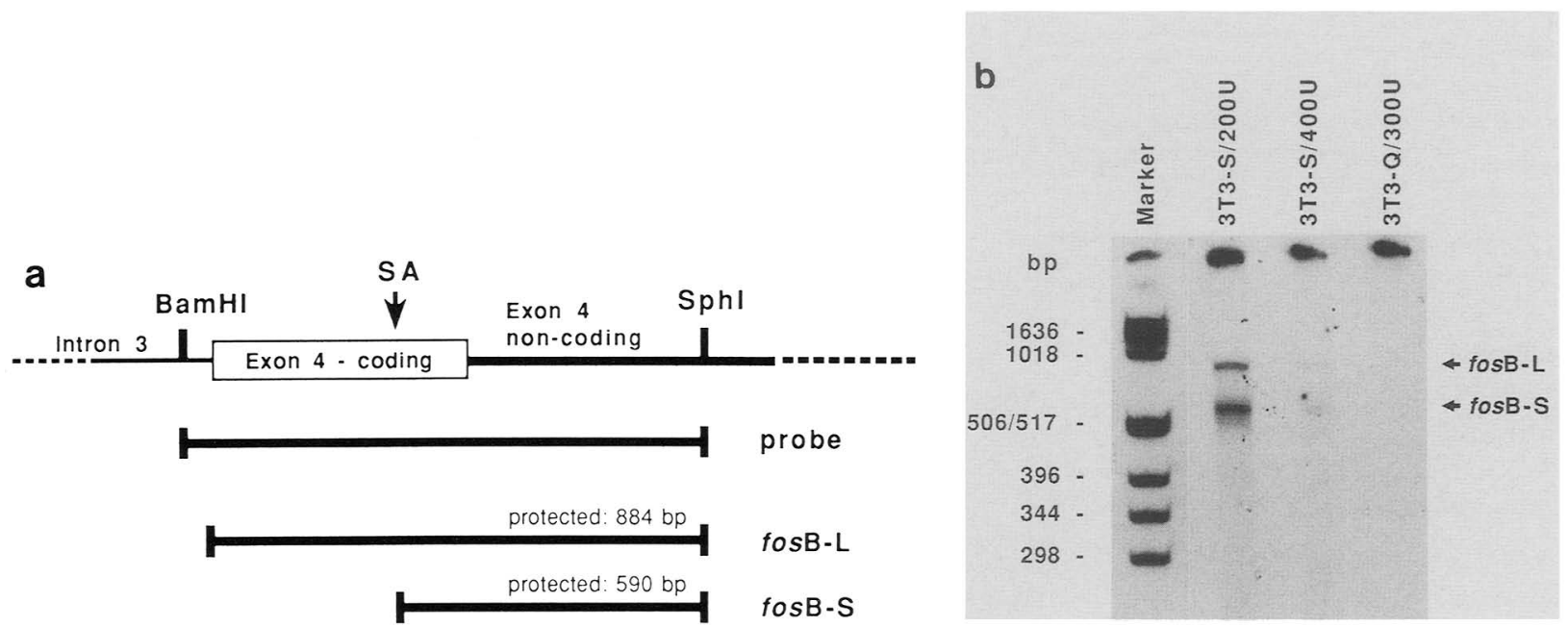

Figure 4. Nuclease $\mathrm{S} 1$ mapping of $f \circ s B$ mRNAs in serum-stimulated NIH-3T3 cells. $(a)$ Schematic representation of the fos $B$ fourth exon, the derived $B a m H I-S p h I$ probe, and the two fragments expected to be protected by fos $B-\mathrm{L}$ and fos $B-S$ mRNA $(884$ and 590 bp, respectively). (SA) Splice acceptor. (b) Separation of DNA fragments after nuclease S1 digestion using the probe shown in $a$ and the DNA samples indicated above the lanes. (3T3-S/200 U) Stimulated (1 hr) NIH-3T3 cells, 200 units of nuclease S1; (3T3-S/400 U) same as lane 1, but 400 units of enzyme; (3T3-Q/300 U) serum-deprived NIH-3T3 cells, 300 units of nuclease S1. Arrows indicate the fragments protected by fos $B-\mathrm{L}$ and $f O S B-S$ RNA, respectively. 


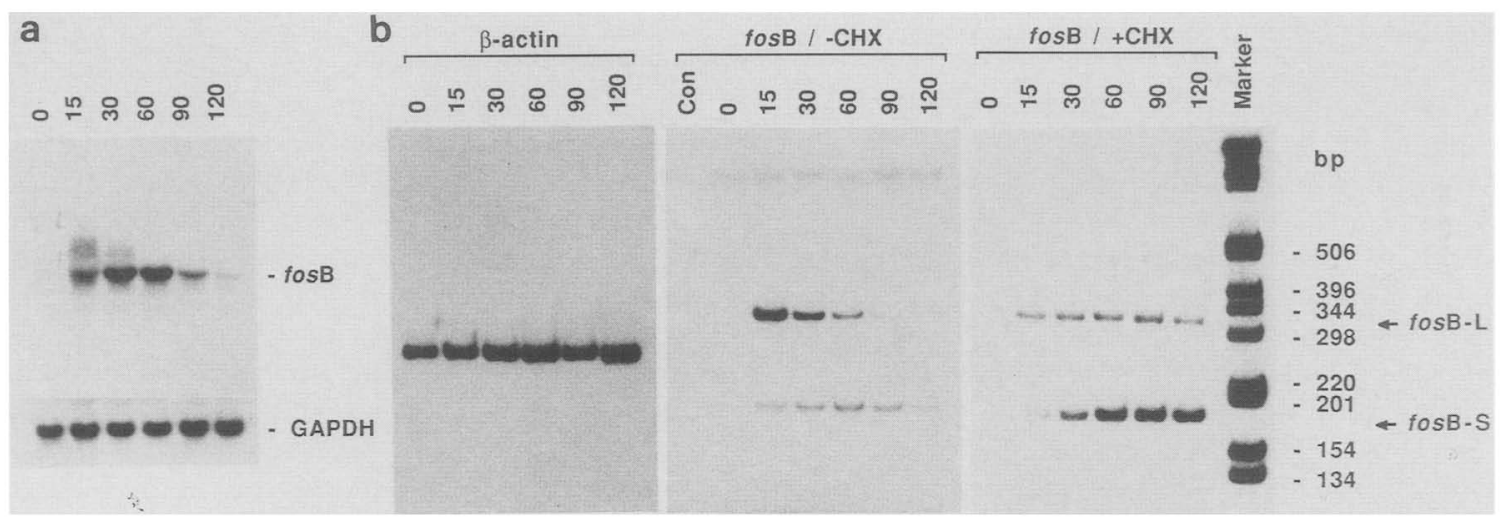

Figure 5. (a) Northern blot analysis of $f \circ s B$ expression after serum stimulation of serum-deprived NIH-3T3 cells. Cells were harvested after the indicated times (minutes) poststimulation. A control blot was hybridized to a GAPDH probe to show that equal amounts of intact RNA were located. The size of the fos $B$ mRNA is $\sim 4 \mathrm{~kb}$. $(b)$ Analysis of $\beta$-actin (control) and fos $B$ (with and without addition of $\mathrm{CHX}$ ) expression after serum stimulation of serum-deprived NIH-3T3 cells by quantitative PCR-mediated cDNA amplification PCR was performed as in Fig. 2. (Con) No RNA added (negative control). In the right-most panel, CHX (5 $\mathrm{kg} / \mathrm{ml}$ ) was added $1 \mathrm{hr}$ prior to serum stimulation.

both proteins should exhibit different or even antagonistic functional properties. To test this possibility, we constructed two plasmids with mutations in either the SD, thus expressing only fos $B-\mathrm{L}$, or with a stop codon at the position of the SD site, thus expressing only the truncated fos $B$-S form. The structures of these plasmids, which were generated by PCR-mediated mutagenesis (see Materials and methods), are shown in Figure 6a. To verify the presence of the mutations and the intactness of the reading frame we cloned the two mutated cDNAs into an in vitro transcription vector and translated the resulting RNA using reticulocylce lysate. Figure 7 [lanes IVT (in vitro-translated)] shows that the translated proteins had the expected molecular masses of $\sim 35$ and $45 \mathrm{kD}$.

The mutant proteins were then inserted into a eukaryotic expression vector containing the SV40 early promoter. To be able to specifically identify mRNAs expressed from these plasmids (after transcription into cDNA and PCR-mediated amplification) we also introduced new restriction sites into constructs $\mathrm{pFosB}-\mathrm{L}$ and pFosB-S, together with the mutations described above.
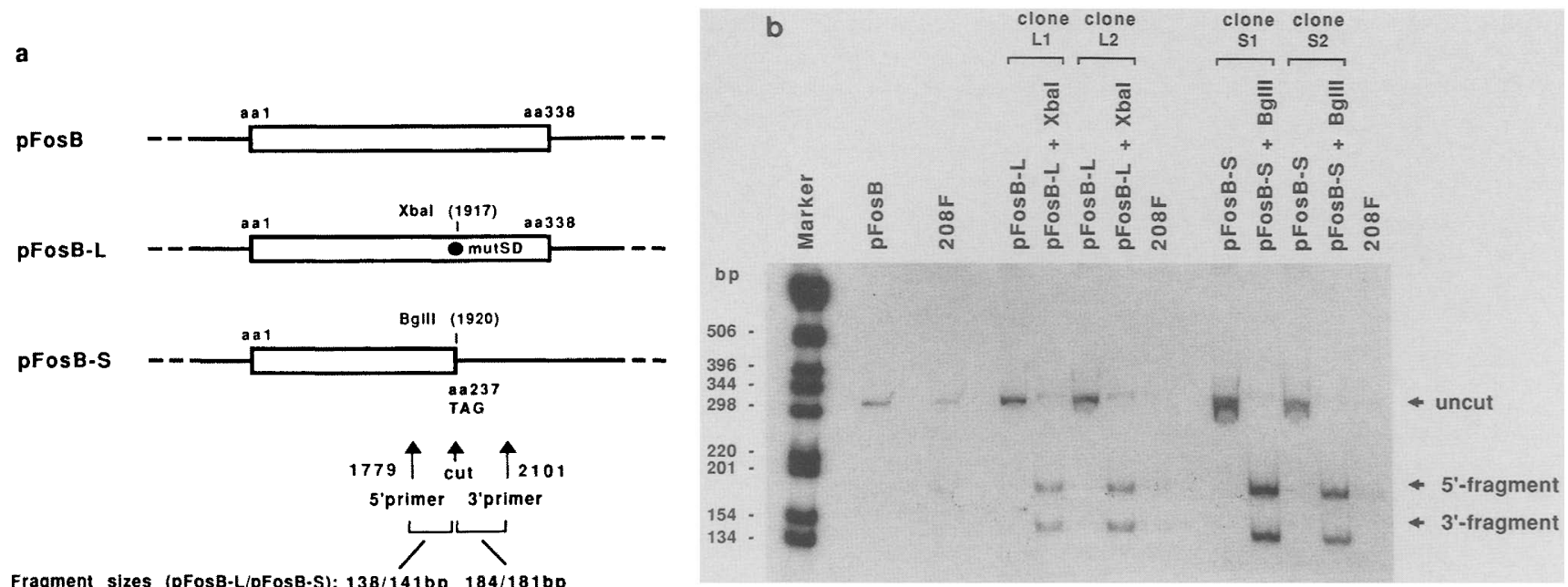

Figure 6. (a) Schematic representation of $f \circ B$ inserts in constructs pFosB, pFosB-L, and pFosB-S. Coding regions are boxed; the solid circle in pFosB-L indicates the mutated splice donor sequence (mutSD); TAG indicates the stop codon introduced into pFosB-S. Together with the mutations, new restriction sites were introduced into $\mathrm{pFosB} / \mathrm{L}$ (XbaI at position 1917 according to Zerial et al. 1989) and pFosB/S (BglII at position 1920). The positions of the $5^{\prime}$ primer $\left(5^{\prime}\right.$ end at 1779$)$ and the $3^{\prime}$ primer $\left(3^{\prime}\right.$ end at 2101$)$ used for PCR analysis are shown at the bottom. Digestion of the PCR products with XbaI or BglII should result in fragments of 138 and 184 bp (pFosB$\mathrm{L}$ ) or 141 and $181 \mathrm{bp}$ (pFosB-S). (b) Expression of fos $B$-L and fosB-S in cell lines stably transfected with pFosB, pFosB-L, or pFosB-S. PCR analysis was performed as in Figs. 2 and 5, except that in the cases indicated the PCR products were digested with XbaI or BgIll. For both pFosB-L and pFosB-S two independent clones (L1/L2 and S1/S2) were analyzed. The arrows (right) indicate the uncut PCR product and the two fragments generated by the indicated restriction enzymes, as explained in $a$. 


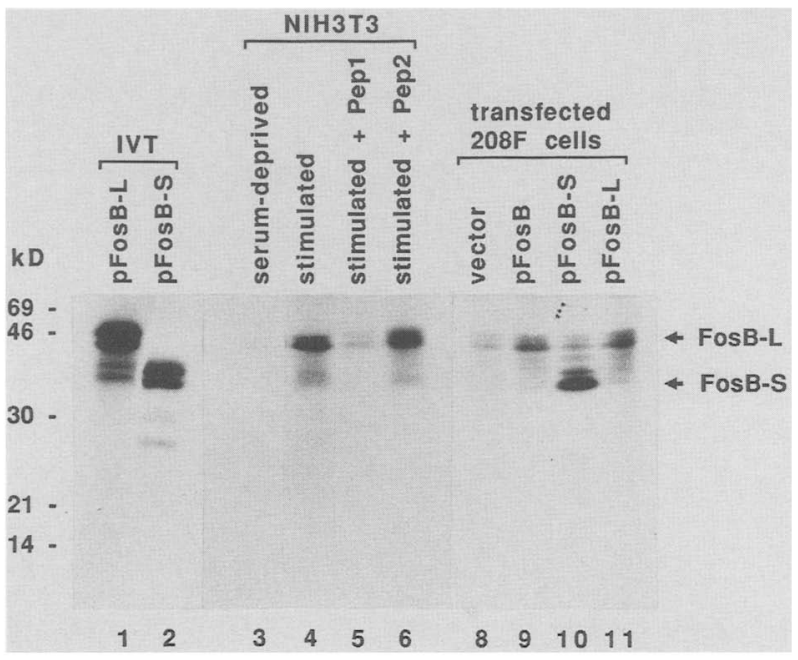

Figure 7. Immunoprecipitation of FosB-L and FosB-S proteins in serum-deprived (lane 3) and serum-stimulated NIH-3T3 cells (40 min poststimulation; lane 4) and in cell lines stably transfected with the empty expression vector pMSE, pFosB, pFosB-L, or pFosB-S (lanes 8-11; see also Fig. 6b, clones L1 and S1). lmmunoprecipitation of the extract from stimulated NIH-3T3 cells was also performed in the presence of either the specific peptide (used as the hapten for immunization; lane 5) or an irrelevant peptide (lane 6) to show the specificity of the immunoprecipitation. Lanes 1 and 2 show the in vitro-translated FosB-L and FosB-S proteins. Arrows at right indicate the two FosB forms of 45 and $35 \mathrm{kD}$ (FosB-L and FosB-S).

Digestion of PCR products from cell lines stably transfected with these plasmids could thus be carried out to verify that the expected exogenous fos $B$ mRNA forms were expressed. Two fos $B$-L-expressing clones $(\mathrm{L} 1, \mathrm{~L} 2)$ and two fos $B$-S-expressing cell lines $(\mathrm{S} 1, \mathrm{~S} 2)$ showed the expected 322-bp fragment, which could be digested with either $X b a I(L 1, L 2)$ or $B g I I I(S 1, S 2)$ to yield two bands of $138 / 184$ and $141 / 181 \mathrm{bp}$, respectively (see Fig. $6 a$ and b). Untransfected $208 \mathrm{~F}$ cells showed a much weaker signal, presumably representing the endogenous fos $B$ mRNA, which is probably also responsible for the weak upper band ("uncut" position) seen in the digested samples.

\section{Expression of Fos B-L and Fos B-S proteins}

The clones of $f \circ B-\mathrm{L}$ - and fos $B$-S-expressing cells described above were then analyzed for the synthesis of the respective FosB proteins. Cells were metabolically pulselabeled with $\left.{ }^{35} \mathrm{~S}\right]$ methionine, lysed in RlPA buffer, treated with SDS to disrupt FosB/Jun complexes, and immunoprecipitated with a FosB-specific antibody raised against the amino-terminal 14 amino acids (kindly provided by Dr. J. Adamkiewicz, IMT). Figure 7 shows that pFosB-L and pFosB-S cells expressed proteins of $\sim 45$ and $35 \mathrm{kD}$, respectively, which comigrated with FosB-L and FosB-S synthesized by in vitro transcription-translation. Similarly sized proteins were also detected in serumstimulated NIH-3T3 cells. Precipitation of the 35- and $45-\mathrm{kD}$ proteins was completely abolished by competi- tion with the specific peptide /used as the hapten for immunization) but not by an unrelated peptide. We therefore conclude that (1) the two endogenous mRNA forms in NIH-3T3 cells are translated into protein, and (2) the constructed plasmids express the expected proteins, corresponding to the endogenous products generated by alternative splicing. Interestingly, transfection of pFosB, which contains an intact SD site, leads to the expression of only FosB-L. This suggests that the alternative splicing mechanism functions only in the context of the primary transcript.

\section{TRE binding of FosB-L/Jun and FosB-S/Jun complexes}

To analyze the DNA-binding properties of the two FosB forms we reconstituted FosB-L/c-Jun and FosB-S/c-Jun complexes from the respective in vitro-translated proteins and analyzed these complexes for binding to an oligonucleotide containing the collagenase TRE. The results of the gel-retardation analysis are shown in Figure 8. As expected, the uncomplexed proteins did not show any significant binding under the conditions of the assay (lanes 1-3), whereas both forms of FosB gave clear shifts at room temperature (lanes 4 and 5) and at $37^{\circ} \mathrm{C}$ (lanes 6 and 7). The observed binding was specific, as it was competed by a 100 -fold excess of the specific TRE oligonucleotide but not by a similar amount of a random oligonucleotide. These results show that both FosB-L and FosB-S are able to bind to the TRE in complexes with c-Jun.

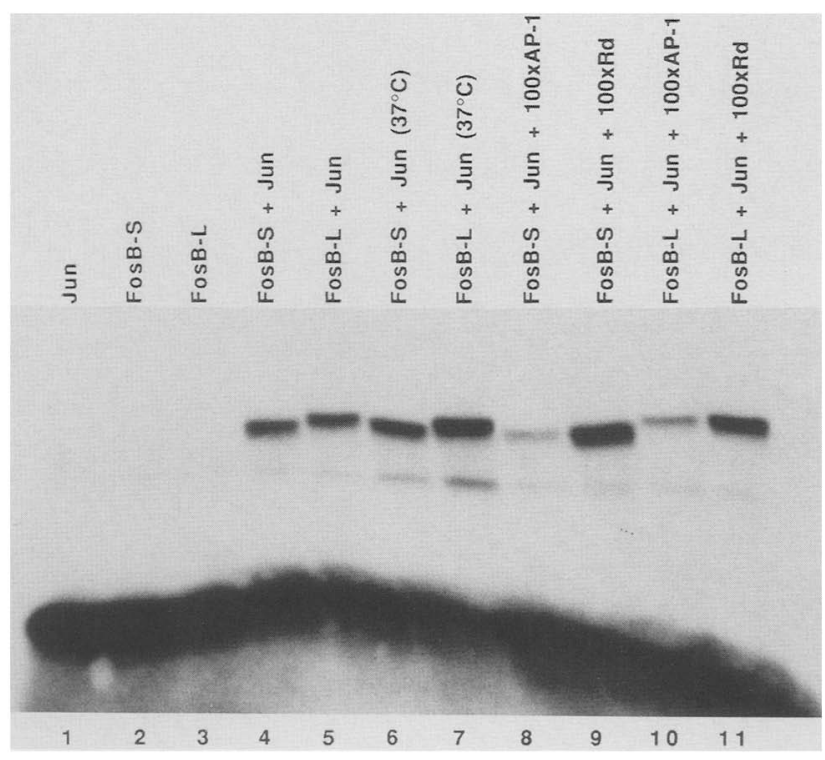

Figure 8. Gel-retardation analysis of FosB-L and FosB-S synthesized by in vitro transcription-translation for binding to the collagenase TRE in the presence or absence of c-Jun. Competitions were performed in the presence of a 100 -fold molar excess of a random (upper strand, 5'-GCGACTAACATCGATCG) or a TRE-containing oligonucleotide (AP-1; upper strand, 5'AAGCAGACAC). 
Trans-regulation by FosB-L and FosB-S

We then tested the trans-activating potential of the FosB-L and FosB-S proteins. Figure 9 shows that in HeLa cells both proteins were able to trans-activate expression of a $5 \times$ TRE-chloramphenicol acetyltransferase (CAT) reporter construct (10- and 7-fold, respectively), similar to pFosB (5-fold). Likewise, the coexpression of pFosB-L and pFosB-S resulted in a five- to sevenfold induction of CAT activity. As controls, two v-Fos expression plasmids were included. Expression of E300 resulted in an 18-fold trans-activation, and an E300 protein with an impaired leucine zipper (L3-4-5; Schuermann et al. 1989) only led to an insignificant increase in CAT activity (twofold). These results indicate that both FosB forms are able to trans-activate the $5 \times$ TRE-CAT construct. Practically identical results were obtained with NIH-3T3 cells as the recipients (data not shown).

To analyze the trans-repression potential of pFosB-L and pFosB-S we tested their effect on a c-fos-promoter/ CAT construct in serum-stimulated cells, as described for c-Fos trans-repression (Lucibello et al. 1989). Figure 10 shows that both pFosB and pFosB-L were able to trans-repress the c-fos-CAT reporter construct by $\sim 65 \%$, whereas pFosB-S was unable to do so. Interestingly, the repression by pFosB-L was suppressed by coexpressed pFosB-S (right-most lane), indicating that the

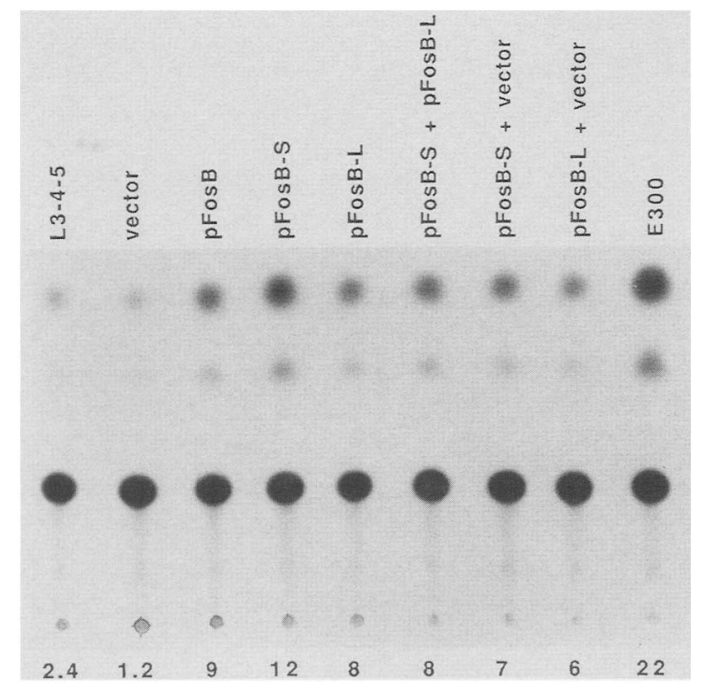

Figure 9. Trans-activation of a $5 \times$ TRE-CAT reporter construct by v-Fos- and FosB-expressing plasmids. HeLa cells were transfected with $2.5 \mu \mathrm{g}$ of reporter plasmid plus $2.5 \mu \mathrm{g}$ of expression vector (lane $6,1.25 \mu \mathrm{g}$ of both pFosB-S and pFosB-L; lanes 7 and $8,1.25 \mu \mathrm{g}$ of pFosB-S or pFosB-L plus $1.25 \mu \mathrm{g}$ of the empty vector). Cells were harvested $48 \mathrm{hr}$ after transfection, and CAT activity was determined. Numbers at the bottom show percent conversion, corrected for transfection efficiency and protein concentration; $100 \%$ conversion corresponds to 1250 pmoles/mg of protein per hour. (L3-4-5) E300 (a v-Fos hybrid; see right-most lane) with a defective leucine zipper due to the mutation of 3 leucines (Schuermann et al. 1989); (vector) the empty expression vector pMSE (Schuermann 1990).

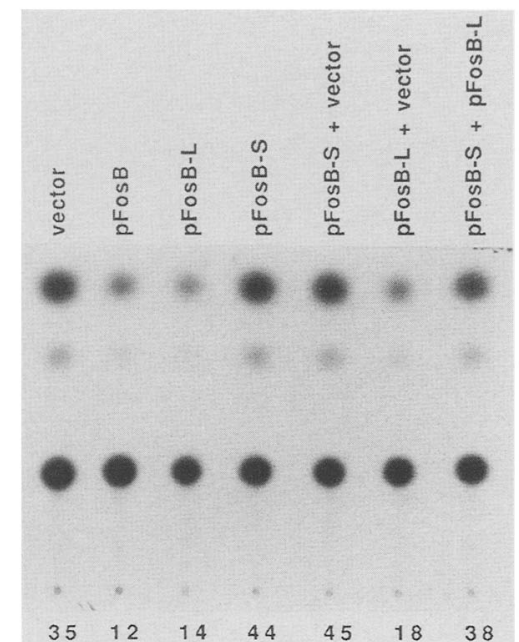

Figure 10. Trans-repression of a c-fos-CAT reporter construct by FosB expression vectors. NIH-3T3 cells were transfected with $2.5 \mu \mathrm{g}$ of reporter plasmid (p $\Delta 6 \mathrm{CAT} 3$; Lucibello et al. 1989) plus $2.5 \mu \mathrm{g}$ of expression vector (lanes 5 and $6,1.25 \mu \mathrm{g}$ of pFosB$\mathrm{L}$ or pFosB-S plus $1.25 \mu \mathrm{g}$ of the empty vector; lane $7,1.25 \mu \mathrm{g}$ of both pFosB-S and pFosB-L). Numbers at the bottom correspond to percent conversion corrected for transfection efficiency and protein concentration. (Vector) Empty expression vector pMSE (Schuermann 1990).

short FosB form is not only incapable of trans-repression but also acts as an antagonist.

\section{Transforming potential of $p F o s B-L$ and $p F o s B-S$}

Finally, we analyzed the transforming properties of the two FosB forms in a focus assay using $208 \mathrm{~F}$ cells as the recipients. The results displayed in Table 1 clearly show that only the long FosB form was able to induce significant numbers of foci: While pFosB and pFosB-L induced 74 and 69 foci, respectively, only 5 and 9 foci were seen with the empty expression vector pMSE and pFosB-S, respectively. It cannot be decided at this point whether

Table 1. Induction of morphological transformation and dominant negative effects by FosB proteins

\begin{tabular}{llc}
\hline Constructs & $\begin{array}{c}\text { Amount } \\
(\mu \mathrm{g})\end{array}$ & $\begin{array}{c}\text { Number of } \\
\text { foci/transfection }\end{array}$ \\
\hline pMSE (vector) & 1 & 5 \\
pFosB & 1 & 74 \\
pFosB/L & 1 & 69 \\
pFosB/S & 1 & 9 \\
pFosB/L + pMSE & $1+1$ & 70 \\
pFosB/L + pFosB/S & $1+1$ & 15 \\
pFosB/L + pMSE & $1+2$ & 84 \\
pFosB/L + pFosB/S & $1+2$ & 18 \\
pFosB/L + pMSE & $1+3$ & 112 \\
pFosB/L + pFosB/S & $1+3$ & 20 \\
\hline
\end{tabular}

${ }^{a}$ Number of foci in three plates 22 days after transfection. 
the transforming potential of pFosB-S is very low or not existent at all, due to the formation of a low number of spontaneous foci in the vector control plates. The reason for the latter is the relatively long time needed for fos $B$ induced foci to become macroscopically visible $\mid>3$ weeks). The focus assay was also performed with $\mathrm{NIH}-$ $3 \mathrm{~T} 3$ cells with very similar results (data not shown).

The very low or absent transforming potential of pFosB-S was not due to a toxic effect, as similar numbers of $\mathrm{G} 418^{\mathrm{R}} 208 \mathrm{~F}$ colonies could be obtained with all constructs $(335$ colonies $/ \mu \mathrm{g}$ of $\mathrm{pFosB} ; 287$ colonies $/ \mu \mathrm{g}$ of pFosB-L; 330 colonies/ $\mu \mathrm{g}$ of pFosB-S), and stable lines expressing FosB-S could also be obtained (see experiments shown in Figs. $6 \mathrm{~b}$ and 7). This result is important in view of the the ability of FosB-S to suppress transformation by pFosB-L: Cotransfection of $1 \mu \mathrm{g}$ of pFosB-L and 1,2 , or $3 \mu \mathrm{g}$ of empty vector DNA yielded between 70 and 112 foci; cotransfer of $1 \mu \mathrm{g}$ of pFosB-L and 1,2 , or $3 \mu \mathrm{g}$ of pFosB-S gave only 15-20 foci. This observation clearly suggests that pFosB-S does not only lack significant transforming properties but also possesses antioncogenic properties with respect to pFosB-L-induced transformation.

\section{Discussion}

Induction of the fos $B$ gene is part of the immediate early response of cells after stimulation with growth factors (Zerial et al. 1989). A cDNA clone representing a $\operatorname{fos} B$ mRNA has been isolated and shown to contain the known structural elements of bZip proteins, that is, a leucine zipper flanked by a basic region representing part of a bipartite DNA-binding domain. Considering the high homology of this region with the c-Fos-bZip domain it was not surprising to find that both proteins show very similar, if not identical, DNA-binding properties in a complex with a Jun protein. In this study we have identified a second $\operatorname{fos} B$ mRNA generated by alternative splicing, whose encoded product (FosB-S) lacks the 101 carboxy-terminal amino acids present in the longer FosB-L protein. This truncation leaves the leucine zipper and the adjacent basic region intact, which is reflected by the ability of both FosB-L and FosB-S proteins to bind cooperatively with c-Jun to TRE. The two fos $B$ mRNA forms are differentially expressed following serum stimulation, the long form preceding the short form by $\sim 30 \mathrm{~min}$. This observation deserves particular attention in view of the fact that the two forms of FosB differ in their transforming and trans-repressing properties: Only FosB-L is able to repress a c-fos-promoter/CAT reporter construct, and FosB-S can suppress the trans-repressing effect of FosB-L. Likewise, only the long form induces transformation efficiently, and this function is also antagonized by FosB-S. These functional differences suggest that the trans-regulatory action of FosB-L, activated upon serum stimulation, is counteracted by the subsequently expressed FosB-S. The consecutive expression of an oncogenic trans-regulator and anti-oncogenic antagonist derived from the same gene represents a novel mechanism regulating the action of Fos family members. The fact that FosB-S is unable to repress the c-fos-promoter construct suggests that a region in the 101 aminoacid carboxy-terminal stretch of FosB-L is required for trans-repression. The carboxyl terminus of FosB-L, which is not well conserved among Fos and FosB, contains a conspicuous cluster of 7 contiguous proline residues followed by another stretch rich in prolines and serines, which might play a role in this type of transregulation by FosB-L. It has been shown that proline-rich domains are involved in transcriptional activation by other proteins (Mitchell and Tiian 1989) and thus represent potential interfaces for protein-protein interactions. However, at least in the cell systems analyzed in the present study (NIH-3T3 fibroblasts and HeLa cells), this region does not seem to be crucial for the other trans-regulatory function of FosB-L, trans-activation of AP-1-dependent transcription, because FosB-S was at least as efficient at activating the $5 \times$ TRE-CAT reporter construct as FosB-L.

It is conceivable that the cell has devised additively acting regulatory mechanisms that keep the potentially oncogenic action of Fos proteins under constraint. It has already been shown that transcriptional activation occurs only at a precise time and only for several minutes following growth factor stimulation (Greenberg and Ziff 1984; Kruijer et al. 1984; Müller et al. 1984), the synthesized mRNA is degraded rapidly with a half-life of $\sim 10$ min (Rahmsdorf et al. 1987), and Fos proteins turn over with short half-lives of 30-120 min (Curran et al. 1984; Müller et al. 1984). In addition, trans-repression by Fos protein has been shown to be dependent on the phosphorylation status of the protein (Ofir et al. 1990). The data reported in this discussion suggest that another mechanism can be added to this list, the counteraction of a specific function exerted by FosB-L, that is, its transrepressing properties, by another product of the same gene generated by differential splicing.

Our results show clearly that FosB-L is an oncoprotein and that the shorter form of FosB possesses only very weak, if any, transforming properties. This is not due to a toxic effect exerted by FosB-S, as all FosB constructs were able to induce similar numbers of $\mathrm{G} 418^{\mathrm{R}}$ colonies. The transforming potential of the FosB constructs does not seem to correlate with their trans-activating potential, because FosB-S does not transform efficiently despite its trans-activating properties. A much better correlation seems to exist between transformation and trans-repression, both of which are efficiently mediated only by FosB-L and suppressed by FosB-S. This observation is particularly interesting in view of the fact that a similar correlation is not found for the induction of transformation by v-Fos and trans-repression (Lucibello et al. 1989). This raises the intriguing possibility that different members of the Fos family use different molecular mechanisms to induce transformation in fibroblasts.

Negative regulation of trans-regulatory proteins by interacting factors has been described in other instances, such as the E-box-binding factors MyoD, E12, and E47, 
whose interaction with DNA is negatively affected by complex formation with the Id protein (Benezra et al. 1990|. Likewise, differential splicing of proto-oncogene transcripts is not a novel feature of fos $B$. It has been shown that alternative splicing is responsible for the tissue-specific expression of c- $a b 1$ (Beh-Neria et al. 1986; Bernards et al. 1988) and c-src (Levy et al. 1987; Wang et al. 1987) mRNAs; and the c-H-ras transcript is subject to differential splicing, although the significance of the shorter form remains obscure (Cohen et al. 1989b). Another interesting example is the alternative splicing of c-myb transcripts, which generates a truncated protein, termed $\mathrm{Mbm} 2$, in addition to the full-length product $\mathrm{c}$ Myb (Weber et al. 1990). Although c-Myb blocks the dimethylsulfoxide (DMSO)-induced differentiation of mouse erythroleukemia cells, the shorter $\mathrm{Mbm} 2$ protein, which lacks the transcriptional regulatory regions, enhances their differentiation (Weber et al. 1990).

These observations suggest that proteins acting at crucial points in proliferation and differentiation-controlling pathways are not only regulated at the level of expression but also by modulation of their activity through post-translational modifications and interaction with other factors. Such multiple regulatory mechanisms might ensure the proper functioning of biological processes that involve the rapid switching between different functional states of the regulatory "master" proteins, as it occurs in the induction of cell division and differentiation by growth factors or hormones. In addition, perturbations in such regulatory networks due to mutations or abnormal environmental situations would not necessarily cause havoc, because other mechanisms might still be able to keep the physiological balance.

Another study reporting alternative splicing of $\operatorname{fos} B$ transcripts has been published (Nakabeppu et al. 1991). Both that study and this one are in agreement with regard to the structure of the alternatively spliced RNAs and the behavior of their products in trans-repression. In contrast to our findings, Nakabeppu et al. report that FosB-S is unable to trans-activate TRE-dependent transcription and can block trans-activation by FosB-L. The other aspects addressed in our study, that is, kinetics of expression and transforming properties of the two FosB forms, were not analyzed by Nakabeppu et al. (1991). Two major differences in the experimental conditions may account for the apparent discrepancy in the transactivation study. Nakabeppu et al. used F9 teratocarcinoma stem cells, which are known to differ from NIH$3 \mathrm{~T} 3$ and HeLa cells in that they contain basically no endogenous AP-1 activity (Chiu et al. 1988). It is conceivable that the availability of endogenous factors acting on AP-1 sites may have a significant influence on the results of the assay. In addition, different reporter constructs were used in the two studies, containing either a single TRE (Nakabeppu et al. 1991) or five copies of the TRE (this study). It is possible that FosB-S shows transactivation properties only with oligomerized binding sites. Further experiments will have to establish the role of cell type and target sequence specificity in FosB-mediated trans-activation.

\section{Materials and methods}

\section{Cell culture}

F9, HeLa, 208F, and 3T3 cells were cultured in Dulbecco-Vogt modified Eagle minimum essential medium (DMEM) supplemented with $10 \%$ fetal calf serum (FCS), $0.5 \%$ glucose, penicilin $(100 \mathrm{U} / \mathrm{ml})$, and streptomycin $(100 \mathrm{mg} / \mathrm{ml})$. Serum-deprived cells were kept for $20 \mathrm{hr}$ in serum-free DMEM and stimulated with $10 \%$ FCS. In some experiments, CHX was added $1 \mathrm{hr}$ before serum stimulation.

\section{Northern blot analysis}

RNA was prepared according to Chirgwin et al. (1979), and Northern blot analysis was performed as described previously (Thomas 1980; Müller et al. 1983).

\section{$P C R$ and analysis of PCR products}

For cDNA synthesis $1 \mu \mathrm{g}$ of total RNA was annealed to $1 \mu \mathrm{g}$ of oligo(dT) and incubated with 200 units of Moloney murine leukemia virus reverse transcriptase for $1 \mathrm{hr}$ at $37^{\circ} \mathrm{C}$ in a final volume of $20 \mu \mathrm{l}$. One-tenth of the reaction mixture was amplified by 25 cycles of PCR (Saiki et al. 1988) in the presence of 0.5 $\mu \mathrm{Ci}$ of $\left[\alpha^{-32} \mathrm{P}\right] \mathrm{dCTP}$. The two oligonucleotide primers used in all PCR experiments had the sequence 5'-AAAAGGCAGAGCTGGAGTCG-3', complementary to nucleotides 1779-1798 of fosB cDNA (Zerial et al. 1989), and 5'-GTACGAAGGGCTAACAACGG-3', complementary to nucleotides 2101-2082, respectively.

\section{Cloning and analysis of the fosB-S PCR fragment}

The PCR-amplified 322 bp containing the fos $B$-S splice junction fragment was purified by agarose-gel electrophoresis, digested with RsaI and HinfI, and blunt-end-ligated in a pTZ18R vector. DNA sequencing was carried out according to Chen and Seeburg (1985) using the Sequenase version 2.0 DNA sequencing kit (U.S. Biochemical).

\section{Nuclease S1 protection analysis}

Nuclease S1 protection analysis was performed essentially as described in Hagen et al. (1990). A genomic SphI fragment was end-labeled with $\left[\gamma^{-32} \mathrm{P}\right] \mathrm{ATP}$ and digested with BamHI, and the resulting BamHI-SphI fragment was isolated by agarose-gel electrophoresis. This probe $\left(2 \times 10^{5} \mathrm{cpm}\right)$ was hybridized overnight at $59^{\circ} \mathrm{C}$ to $30 \mu \mathrm{g}$ of total RNA from quiescent cells or from cells stimulated with $10 \%$ FCS for $1 \mathrm{hr}$. Nuclease S1 digestions were carried out for $1 \mathrm{hr}$ at $37^{\circ} \mathrm{C}$.

\section{In vitro transcription-translation}

The in vitro transcription-translation of FosB-S, FosB-L, and Jun proteins was performed as described in Schuermann et al. (1989).

\section{Gel retardation analysis}

Binding reactions were performed by incubating $5 \mu l$ of FosB-S or FosB-L and $5 \mu \mathrm{l}$ of Jun-containing in vitro translation mixtures with $1.5 \mu \mathrm{g} / \mathrm{ml}$ poly[d(I-C)] in a buffer containing $10 \mathrm{mM}$ HEPES (pH 7.9), $60 \mathrm{~mm} \mathrm{KCl}, 4 \%$ Ficoll, $1 \mathrm{~mm}$ EDTA, and $1 \mathrm{~mm}$ dithiothreitol for $60 \mathrm{~min}$ on ice. Approximately $2.5 \times 10^{4} \mathrm{cpm}$ of labeled double-stranded oligonucleotide containing an AP1 -binding site was added, and incubation was continued for an- 
Table 2. Sequences of oligonucleotides used for PCR-mediated mutagenesis

\begin{tabular}{|c|c|}
\hline \multirow{3}{*}{ FosB-S1 } & EcoRI \\
\hline & $5^{\prime}$-GGGAATTC $-\underline{1913}_{13}$ TAGAGAGATCTGCCAGGGTCAACATCCG $1943^{3}{ }^{\prime}$ \\
\hline & $-\quad B g / I I I \quad$ HindIII \\
\hline \multirow{2}{*}{ FosB-S2 } & $3^{\prime}{ }_{1897}$ TCCGGGCGACCGGCTCATCTCTCTAGA -1923 TTCGAAGG-5' \\
\hline & $\begin{array}{lll}E c o R I & X b a I\end{array}$ \\
\hline \multirow[t]{2}{*}{ FosB-L1 } & $5^{\prime}$-GGGAATTC $-19{ }_{13}$ CTTCTAGATTTGCCAGGGTCAACAT $_{1937^{-}} 3^{\prime}$ \\
\hline & {$[\quad X b a \mathrm{I} \quad$ HindIII } \\
\hline FosB-L2 & $\begin{array}{l}3^{\prime}{ }_{-1897} \text { TCCGGGCGACCGGCTCGAAGATCT }_{\text {EcoRI }} \\
\text { 1920 TTCGAAGG-5' }\end{array}$ \\
\hline \multirow[t]{2}{*}{ FosB-P } & $5^{\prime}$-GGGAATTC -1705 TGCAGCTAAGTGCAGGAA ${ }_{1722^{-3}}{ }^{\prime}$ \\
\hline & HindIII \\
\hline FosB-N & $3^{\prime}{ }_{-2134}$ CAGGCGCAAGCGGCCG $_{-2149}{ }^{\text {TTCGAAGG }-5 '}$ \\
\hline
\end{tabular}

other $60 \mathrm{~min}$ at either room temperature or $37^{\circ} \mathrm{C}$. The reaction mixtures were separated on $4 \%$ polyacrylamide gels at $10 \mathrm{~V} / \mathrm{cm}$ (Barberis et al. 1987).

\section{Immunoprecipitations}

$208 \mathrm{~F}$ cells transfected with pFosB, pFosB-S, pFosB-L, or empty expression vector were selected in G418-containing medium, as described above, and grown to confluency. Prior to labeling with $\left[{ }^{35} \mathrm{~S} \mid\right.$ methionine, the cells were kept in serum-free medium for $18 \mathrm{hr}$. Metabolic labeling and the subsequent preparation of lysates were performed according to Jenuwein and Müller (1987). To disrupt protein complexes (e.g., Fos/Jun), aliquots of lysate were heated at $95^{\circ} \mathrm{C}$ for $5 \mathrm{~min}$ in the presence of $0.5 \%$ SDS, cooled down to room temperature, and diluted with RIPA buffer without SDS to give a final SDS concentration of $0.1 \%$. Eight microliters of rabbit polyclonal anti-peptide antiserum, raised against a FosB peptide spanning the amino-terminal 14 amino acids of the FosB protein (kindly provided by Dr. J. Adamkiewicz), was added to $100 \mu \mathrm{l}$ of cleared lysate and incubated on ice for $2-3 \mathrm{hr}$, followed by the addition of $60 \mu \mathrm{l}$ of protein ASepharose and incubation for $60 \mathrm{~min}$ on ice. Washing of immune complexes, gel electrophoresis, and subsequent processing of the gels were performed as described in Schuermann et al. (1989).

\section{PCR-mediated mutagenesis}

The PCR protocols described above were also used to introduce site-specific mutations in the cloned fos $B$ cDNA. Two pairs of oligonucleotides were designed, one to change codon 238 (valine) into a stop codon (TGA), and a second one to destroy the splice donor site following codon 237 (glutamic acid). In addition, two primers, located $\sim 200 \mathrm{bp}$ in either direction from the mutation site, were chosen. All primers also contained suitable restriction sites, which allowed subsequent directional cloning and new internal sites to facilitate their identification (BgIII and $X b a I)$. Numbers in Table 2 indicate nucleotide positions according to Zerial et al. (1989).

FosB-S1 and FosB-L1 oligonucleotides were combined with primer FosB-N to amplify 197 bp of $f o s B$ cDNA fragments. FosB$\mathrm{S} 2$ and FosB-L2 in combination with primer FosB-P yielded fragments of $219 \mathrm{bp}$. All cDNA fragments obtained were digested with EcoRI and HindIII and cloned into pTZ18R. The resulting clones were sequenced to verify the presence of the mutations and the correct reading frame. The subcloned FosB-S fragments were then fused via their BglII sites, and the subcloned FosB-L fragments were ligated via their $\mathrm{XbaI}$ sites. This step was followed by the addition of $3^{\prime}$ FosB cDNA sequences inserted as a
HincII (partial digest)-HindIII fragment. The resulting fos $B$ genes, which were still missing the amino termini, were excised with $P_{\text {St I }}$ to replace the $1.1-\mathrm{kb}$ Pst I carboxy-terminal part of the original pTZfosB cDNA clone. Finally, the reconstituted fos $B-S$ and $f O S B-\mathrm{L}$ genes were excised with $S s t I$ and $X h o I$, ligated to $B a m H I$ linkers, and cloned into pMSE under the control of the SV40 early promoter (Schuermann 1990).

\section{Focus assay}

$208 \mathrm{~F}$ or NIH-3T3 cells $\left(4 \times 10^{5}\right)$ were transfected $24 \mathrm{hr}$ after plating with plasmid DNA purified on $\mathrm{CsCl}$ gradients plus NIH3T3 carrier DNA to give a total amount of $10 \mu \mathrm{g}$ of DNA per transfection. In the case of $208 \mathrm{~F}$ cells, the medium was withdrawn after $4 \mathrm{hr}$, and the cells were washed twice with phosphate-buffered saline (PBS). Twenty-four hours after transfection, the cultures were split in a $1: 3$ ratio. The medium was changed every 3-4 days. Foci of morphologically altered cells were counted after $22-25$ days. The formation of G418 ${ }^{\mathrm{R}}$ colonies was also determined by transfecting $1 \mu \mathrm{g}$ of plasmid DNA plus $5 \mu \mathrm{g}$ of NIH-3T3 carrier DNA and growing the transfected cells in selective medium containing $0.7 \mathrm{mg}$ of $\mathrm{G} 418 / \mathrm{ml}$ as described in Jenuwein et al. (1985).

\section{CAT assays}

Transfections were essentially carried out according to Lucibello et al. (1988). After trypsinization, $4 \times 10^{5} \mathrm{HeLa}$ or $1 \times 10^{5}$ NIH-3T3 cells were seeded per $3-\mathrm{cm}$ plate and transfected $24 \mathrm{hr}$ later. Following transfection, $2.5 \mu \mathrm{g}$ of the reporter plasmid [5 $\mathrm{x}$ TREtkcat 3 for trans-activation and the c-fos-CAT plasmid p $46 C A T 3$ (Lucibello et al. 1989) for trans-repression] was coprecipitated with a total of $2.5 \mu \mathrm{g}$ of expression vector and empty vector DNA, as indicated in the legends to Figures 7 and 8. The DNA precipitate was left on the cells overnight. In transactivation assays, cells were then washed twice with PBS and incubated with DMEM plus $10 \%$ FCS for $24 \mathrm{hr}$. For serum stimulation, 10\% FCS was added to the NIH-3T3 cells $36 \mathrm{hr}$ after transfer to serum-free medium. Cells were lysed in situ in 125 $\mu \mathrm{l}$ of lysis buffer, and $10-50 \mu \mathrm{l}$ was used to determine CAT activity, as described by Gorman et al. (1982). Thin-layer chromatography plates were evaluated using a Packard beta imaging scanner. Protein concentrations were determined with a commercial assay kit (Bio-Rad), and activities were corrected accordingly. In some experiments, the transfection efficiency was monitored by cotransfection of a Rous sarcoma virus (RSV)$l a c Z$ construct and determination of $\beta$-galactosidase activity. 


\section{Acknowledgments}

We are grateful to B. Herber, B. Poensgen, and G. Hagen for technical advice, to Dr. R. Bravo for the mouse c-Jun cDNA clone, to Dr. P. Herrlich for the $5 \times$ TRE-CAT construct, to Dr. J. Adamkiewicz for FosB-specific antibodies, to Dr. H.-J. Brüller for synthesis of oligonucleotides, and to I. Kaminski for help in preparation of the manuscript. This work was supported by the Deutsche Forschungsgemeinschaft (SFB215/D8 and Mu601/5-1) and the Dr. Mildred Scheel Stiftung for Krebsforschung.

The publication costs of this article were defrayed in part by payment of page charges. This article must therefore be hereby marked "advertisement" in accordance with 18 USC section 1734 solely to indicate this fact.

\section{References}

Almendral, J.M., D. Sommer, H. Macdonald-Bravo, J. Burckhardt, J. Perera, and R. Bravo. 1988. Complexity of the early genetic response to growth factors in mouse fibroblasts. Mol. Cell. Biol. 8: 2140-2148.

Angel, P., M. Imagawa, R. Chiu, B. Stein, R.J. Imbra, H.J. Rahmsdorf, C. Jonat, P. Herrlich, and M. Karin. 1987. Phorbol ester-inducible genes contain a common cis element recognized by a TPA-modulated trans-acting factor. Cell 49: 729-739.

Barberis, A., G. Saperti-Furga, and M. Busslinger. 1987. Mutually exclusive interaction of the CCAAT-binding factor and a displacement protein with overlapping sequences of a histone gene promoter. Cell 50: 347-359.

Beh-Neria, Y., A. Bernards, M. Paskind, G.Q. Daly, and D. Baltimore. 1986. Alternative $5^{\prime}$ exons in c-abl mRNA. Cell 44: 577-586.

Benezra, R., R.L. Davis, D. Lockshon, D.L. Turner, and H. Weintraub. 1990. The protein Id: A negative regulator of helixloop-helix DNA binding proteins. Cell 61: 49-59.

Bernards, A., M. Paskind, and D. Baltimore. 1988. Four murine c- $a b l$ mRNAs arise by usage of two transcriptional promoters and alternative splicing. Oncogene 2: 297-304.

Chen, E.Y. and P.H. Seeburg. 1985. Supercoil sequencing: A fast and simple method for sequencing plasmid DNA. DNA 4: $165-170$.

Chirgwin, J.M., A.E. Przybyla, R.I. MacDonald, and W.J. Rutter. 1979. Isolation of biologically active ribonucleic acid from sources enriched in ribonuclease. Biochemistry 18: 5294 5299.

Chiu, R., W.J. Boyle, J. Meek, T. Smeal, T. Hunter, and M. Karin. 1988. The c-Fos protein interacts with c-jun/AP-1 to stimulate transcription of AP-1 responsive genes. Cell 54:541552.

Cochran, B.H., A.C. Reffel, and C.D. Siles. 1983. Molecular cloning of gene sequences regulated by platelet-derived growth factor. Cell 33: 939-947.

Cohen, D.R. and T. Curran. 1988. Fra-1: A serum-inducible, cellular immediate-early gene that encodes a Fos-related antigen. Mol. Cell. Biol. 8: 2063-2069.

Cohen, D.R., P.C.P. Ferreira, R. Gentz, B.R.F. Franza, and T. Curran. 1989a. The product of a fos-related gene, fra-1, binds cooperatively to the AP-1 site with Jun: Transcription factor AP-1 is comprised of multiple protein complexes. Genes \& Dev. 3: $173-184$.

Cohen, J.B., S.D. Broz, and A.D. Levinson. 1989b. Expression of $\mathrm{H}$-ras protooncogene is controlled by alternative splicing. Cell 58: 461-472.

Curran, T. and B.R. Franza, Jr. 1988. fos and jun: The AP-1 connection. Cell 55: 395-397.
Curran, T., A.D. Miller, L. Zokar, and I.M. Verma. 1984. Viral and cellular Fos proteins: A comparative analysis. Cell 36: $259-268$.

Gentz, R., F.J. Rauscher III, C. Abate, and T. Curran. 1989. Parallel association of Fos and Jun leucine zippers juxtaposes DNA binding domains. Science 243: 1695-1699.

Gorman, C.M., G.T. Merlino, M.C. Willingham, I. Pastan, and B.H. Howard. 1982. The Rous sarcoma virus long terminal repeat is a strong promoter when introduced into a variety of eukaryotic cells by DNA-mediated transfection. Proc. Natl. Acad. Sci. 79: 6777-6781.

Greenberg, M.E. and E.B. Ziff. 1984. Stimulation of 3T3 cells induces transcription of the c-fos proto-oncogene. Nature 311: 433-438.

Hagen, G., M. Wolf, S.L. Katyal, G. Singh, M. Beato, and G. Suske. 1990. Tissue specific expression, hormonal regulation and 5 -flanking gene region of the rat Clara cell $10 \mathrm{kD}$ protein: Comparison to rabbit uteroglobin. Nucleic Acids Res. 18: 2939-2946.

Halazonetis, T.D., K. Georgopoulos, M.E. Greenberg, and P. Leder. 1988. c-Jun dimerizes with itself and with c-Fos, forming complexes of different DNA binding affinities. Cell 55: 917924.

Herrlich, P. and H. Ponta. 1989. Nuclear oncogenes convert extracellular stimuli into changes in the genetic program. Trends Genet. 5: 112-116.

Hirai, S.I., R.P. Ryseck, F. Mechta, R. Bravo, and M. Yaniv. 1989. Characterization of junD; A new member of the jun protooncogene family. EMBO /. 8: 1433-1439.

Jenuwein, T. and D. Müller. 1987. Structure-function analysis of Fos protein: A single amino acid change activates the immortalizing potential of v-fos. Cell 48: 647-657.

Jenuwein, T., D. Müller, T. Curran, and R. Muller. 1985. Extended life span and tumorigenicity of nonestablished mouse connective tissue cells transformed by the fos oncogene of FBR-MuSV. Cell 41: 629-637.

Jonat, G., H.J. Ramsdorf, K.K. Park, A.C.B. Cato, S. Gebel, H. Ponta, and P. Herrlich. 1990. Antitumor promotion and antiinflammation: Down-modulation of AP-1 (Fos/Jun) activity by glucocorticoid hormone. Cell 66: 1189-1204.

Kelly, K., B.H. Cochran, C.D. Stiles, and P. Leder. 1983. Cellspecific regulation of the c-myc gene by lymphccyte mitogens and platelet-derived growth factor. Cell 35: 603-610.

König, H., H. Ponta, U. Rahmsdorf, M. Büscher, A. Schönthal, H.J. Rahmsdorf, and P. Herrlich. 1989. Autoregulation of fos: The dyad symmetry element is the major target of repression. EMBO J. 8: 2559-2566.

Kouzarides, T. and E. Ziff. 1988. The role of the leucine zipper in the Fos-Jun interaction. Nature 336: 646-651.

Kruijer, W., J.A. Cooper, T. Hunter, and I.M.Verma. 1984. Platelet-derived growth factor induces rapid but transient expression of the c-fos gene and protein. Nature 312: 711-716.

Lee, W., P. Mitchell, and R. Tjian. 1987. Purified transcription factor AP-1 interacts with TPA-inducible enhancer elements. Cell 49: 741-752.

Levy, J.B., T. Dorai, L.-H. Wang, and J.S. Brugge. 1987. The structurally distinct from of pp60 c-src detected in neuronal cells is encoded by a unique c-src mRNA. Mol. Cell. Biol. 7: 4142-4145.

Lucibello, F.C., M. Neuberg, J.B. Hunter, T. Jenuwein, M. Schuermann, R. Wallich, B. Stein, A. Schönthal, P. Herrlich, and R. Müller. 1988. Transactivation of gene expression by fos protein: Involvement of a binding site for the transcription factor AP-1. Oncogene 3: 43-51.

Lucibello, F.C., C. Lowag, M. Neuberg, and R. Müller. 1989. Trans-repression of the mouse c-fos promoter: A novel 
mechanism of fos-mediated trans-regulation. Cell 59: 9991007.

Lucibello, F.C., E.P. Slater, K.U. Jooss, M. Beato, and R. Müller. 1990. Mutual trans-repression of Fos and the glucocorticoid receptor: Involvement of a functional domain in Fos which is absent in FosB. EMBO J. 9: 2827-2834.

Lucibello, F.C., M. Neuberg, T. Jenuwein, and R. Müller. 1991. Different domains in v-Fos protein contribute to transactivation and transformation. New Biol. (in press).

Matsui, M., M. Tokuhara, Y.N.N. Konuma, and R. Ishizaki. 1990. Isolation of human fos-related genes and their expression during monocyte-macrophage differentiation. Oncogene 5: 249-255.

Meijlink, F., T. Curran, A.D. Miller, and I.M. Verma. 1985. Removal of a 67-base-pair sequence in the noncoding region of protooncogene fos converts it to a transforming gene. Proc. Natl. Acad. Sci. 82: 4987-4991.

Miller, A.D., T. Curran, and I.M. Verma. 1984. c-fos protein can induce cellular transformation: A novel mechanism of activation of a cellular oncogene. Cell 36: 51-60.

Mitchell, P.J. and R. Tjian. 1989. Transcriptional regulation in mammalian cells. Science 245: 371-378.

Müller, R., D.J. Slamon, E.D. Adamson, J.M. Tremblay, D. Müller, M.J. Cline, and I.M. Verma. 1983. Transcription of c-onc genes c-ras ${ }^{\mathrm{Ki}}$ and $\mathrm{c}-\mathrm{fms}$ during mouse development. Mol. Cell. Biol. 3: 1062-1069.

Müller, R., R. Bravo, J. Burckhardt, and T. Curran. 1984. Induction of $\mathrm{c}$-fos gene and protein by growth factors precedes activation of c-myc. Nature 312: 716-720.

Nakabeppu, Y. and D. Nathans. 1991. A naturally occurring truncated form of FosB that inhibits Fos/Jun transcriptional activity. Cell 64: 751-759.

Nakabeppu, Y., K. Ryder, and D. Nathans. 1988. DNA binding activities of three murine Jun proteins: Stimulation by Fos. Cell 55: 907-915.

Neuberg, M., M. Schuermann, J.B. Hunter, and R. Müller. 1989. Two functionally different regions in Fos are required for the sequence-specific DNA interaction of the Fos/Jun protein complex. Nature 338: 589-590.

Neuberg, M., M. Schuermann, and R. Müller. 1991. Transformation by Fos: Requirement for a functional DNA binding site and evidence for cooperation with c-Jun. Oncogene (in press).

Nishina, H., H. Sato, T. Suzuki, M. Sato, and H. Iba. 1990. Isolation and characterization of fra-2, an additional member of the fos gene family. Proc. Natl. Acad. Sci. 87: 3619-3623.

Ofir, R., V.J. Dwarki, D. Rashid, and I.M. Verma. 1990. Phosphorylation of the C-terminus of Fos protein is required for transcriptional transrepression of the c-fos promoter. Nature 348: $80-82$.

Rahmsdorf, H.J., A. Schönthal, P. Angel, M. Litfin, U. Ruther, and P. Herrlich. 1987. Posttranscriptional regulation of $\mathrm{c}$-fos mRNA expression. Nucleic Acids Res. 15: 1643-1659.

Rauscher, F.J. III, D.R. Cohen, T. Curran, T.J. Bos, P.K. Vogt, D. Bohmann, R. Tjian, and B.R. Franza. 1988a. Fos-associated protein $(\mathrm{p} 39)$ is the product of the jun proto-oncogene. $S \mathrm{ci}$ ence 240: 1010-1016.

Rauscher, F.J. III, P.J. Voulalas, B.R. Franza, Jr., and T. Curran. 1988 b. Fos and Jun bind cooperatively to the AP-1 site: Reconstitution in vitro. Genes \& Dev. 2: 1687-1699.

Ryder, K., L.F. Lau, and D. Nathans. 1988. A gene activated by growth factors is related to the oncogene v-jun. Proc. Natl. Acad. Sci. 85: 1487-1491.

Ryder, K., A. Lanahan, E. Perez-Albuerne, and D. Nathans. 1989. Jun-D: A third member of the Jun gene family. Proc. Natl. Acad. Sci 86: 1500-1503.
Ryseck, R.-P., S.I. Hirai, M. Yaniv, and R. Bravo. 1988. Transcriptional activation of c-iun during the G0/G1 transition in mouse fibroblasts. Nature 334: 535-539.

Saiki, R.K., D.H. Gelfand, S. Stoffel, S.J. Scharf, H. Russell, G.T. Horn, K.B. Mullis, and H.A. Erlich. 1988. Primer directed enzymatic amplification of DNA with a thermostable DNA polymerase. Science 239: 487-491.

Sassone-Corsi, P., W.W. Lamph, M. Kamps, and I.M. Verma. 1988a. Fos-associated cellular p39 is related to nuclear transcription factor AP1. Cell 54: 553-560.

Sassone-Corsi, P., J.C. Sisson, and I.M. Verma. 1988b. Transcriptional autoregulation of the proto-oncogene fos. Nature 334: 314-319.

Schönthal, A., P. Herrlich, H.J. Rahmsdorf, and H. Ponta. 1988. Requirement for fos gene expression in the transcriptional activation of collagenase by other oncogenes and phorbol esters. Cell 54: 325-334.

Schuermann, M. 1990. An expression vector system for stable expression of oncogenes. Nucleic Acids. Res. 18: 4945-4946.

Schuermann, M., M. Neuberg, J.B. Hunter, T. Jenuwein, R.-P. Ryseck, and R. Müller. 1989. The leucine repeat motif in Fos protein mediates complex formation with Jun/API and is required for transformation. Cell 56: 507-516.

Schütte, J., J. Viallet, M. Nau, S. Segal, J. Fedorko, and J. Minna. 1989. irn-B inhibits and c-fos stimulates the transforming and trans-activating activities of c-jun. Cell 59: 987-997.

Thomas, P.S. 1980. Hybridization of denatured RNA and small DNA fragments transferred to nitrocellulose. Proc. Natl. Acad. Sci. 77: 5201-5205.

Turner, R. and R. Tjian. 1989. Leucine repeats and an adjacent DNA binding domain mediate the formation of functional cFos-cJun heterodimers. Science 243: 1689-1694.

Wang, L.-H., S. Ijima, T. Dorai, and B. Lin. 1987. Regulation of the expression of proto-oncogene c-src by alternative RNA splicing in chicken skeletal muscle. Oncogene Res. 1: 4359.

Weber, B.L., E.H. Westin, and M.F. Clarke. 1990. Differentiation of mouse erythroleukemia cells enhanced by alternatively spliced c-myb mRNA. Science 249: 1291-1293.

Zerial, M., L. Toschi, R.-P. Ryseck, M. Schuerman, R. Müller, and R. Bravo. 1989. The product of a novel growth factor activated gene, fos $\mathrm{B}$, interacts with Jun proteins enhancing their DNA binding activity. EMBO I. 8: 805-813. 


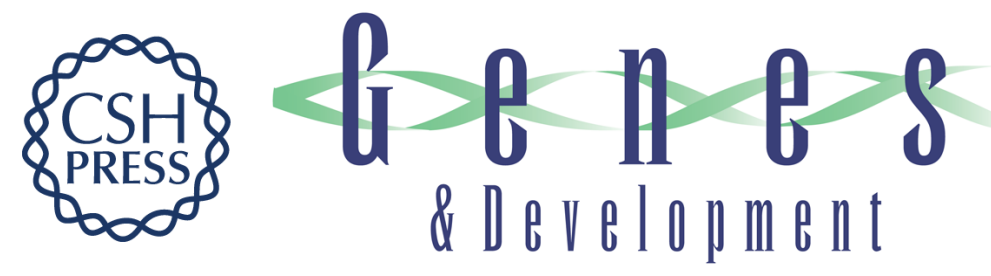

\section{Alternative splicing of fos $B$ transcripts results in differentially expressed mRNAs encoding functionally antagonistic proteins.}

D Mumberg, F C Lucibello, M Schuermann, et al.

Genes Dev. 1991, 5:

Access the most recent version at doi:10.1101/gad.5.7.1212

References This article cites 63 articles, 18 of which can be accessed free at:

http://genesdev.cshlp.org/content/5/7/1212.full.html\#ref-list-1

License

Email Alerting

Service

Receive free email alerts when new articles cite this article - sign up in the box at the top right corner of the article or click here.

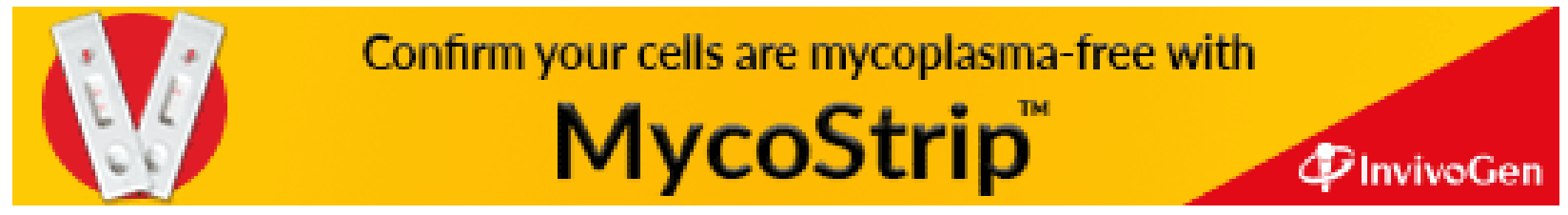

